\title{
ПОИСК НОВЫХ АНТИКОАГУЛЯНТНЫХ СОЕДИНЕНИЙ СРЕДИ АНАЛОГОВ ПУРИНОВЫХ ОСНОВАНИЙ
}

\author{
В.Л. Русинов ${ }^{1}$, С.К. Котовская', К.В. Саватеев', Н.Н. Мочульская', \\ А.А. Спасов ${ }^{2}$, А.Ф. Кучерявенко ${ }^{2}$, П.М. Васильев², В.С. Сиротенко², \\ К.А. Гайдукова ${ }^{2}$, Г.М. Усков ${ }^{2}$
}

\author{
1Уральскийфедеральный университет имени первого Президента России \\ Б.Н. Ельцина, 620002, Россия, г. Екатеринбург, ул. Мира, 19. \\ ²Волгоградский государственный медицинский университет, \\ 400066, Россия, г. Волгоград, пл. Павших Борцов, 1.
}

DOI: 10.19163/MedChemRussia2021-2021-92_E-mail: aidakucheryavenko@yandex.ru

Снижение коагуляционногозвена гемостаза является главной стратегией для предотвращения тромботических состояний, в том числе и в условиях экспериментального цитокинового шторма, который возникает при COVID-19. Использование новых оральных антикоагулянтов дабигатранаэтексилата и апиксабанасущественно снижает риск развития таких осложнений. Однако данные препараты закупаются за рубежом и имеют высокую стоимость. Поэтому поиск новых антикоагулянтныхсоединений является важным аспектом.

Выполнен компьютерный прогноз с целью выявления подобия основным скаффолдам, определяющим антикоагулянтное действие лекарств. Разработаны методы синтеза аналогов пуриновых оснований, азолоазинов различного строения: производных 1,2,4-триазоло[1,5-а] пиримидинов - дезазааналогов противовирусного препарата триазавирина, и пирроло[1,2-f] $[1,2,4]$ триазинов - аналогов противовирусного препарата ремдесивира.

1.<smiles>[R]c1n[nH]c(N)n1</smiles>

2. $R$ = фур-1-ил, этоксикарбонил

3.1:X = $\mathrm{NO}_{2}$ - этиловый эфир этоксиметиленнитроуксусной кислоты, ледяная уксусная кислота, пиридин

4. X = COOЕt-этоксиметилендиэтилмалонат, ледяная уксусная кислота. 2: $\mathrm{NaOH}$, дистиллированная вода

5.

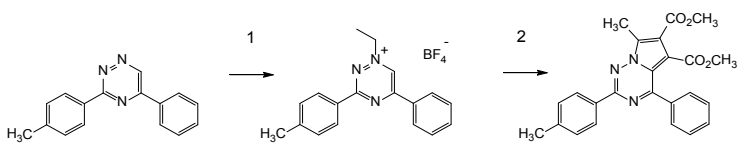

6. 1: $\mathrm{BF}_{3} \mathrm{Et}_{2} \mathrm{O}$, Эпихлоргидрин, Et $\mathrm{O}_{2}$ абс, ЕtOH абс, дихлорэтан;2: Диметилацетилендикарбоксилат, триэтиламин, диоксан, ЕtОН абс.

В результате скрининга 25 новых соединений invitro были выявлены вещества, превосходящие ингибитор Ila фактора дабигатранаэтексилат по способности удлинять тромбиновое время как без, так и в условиях цитокиновой интоксикации.

This work was supported by the Ministry of Science and Higher Education of the Russian

Federation, Grant № 075-15-2020-777. 